\title{
Importance of isolated forest fragments and low intensity agriculture for the long-term conservation of the green peafowl Pavo muticus
}

\author{
Nay Myo Shine, Niti Sukumal, Khin Maung Oo, Simon Dowell \\ STEPHEN BROWNE and TOMMASO SAVINI
}

\begin{abstract}
Low intensity subsistence agriculture is generally believed to be less damaging to wildlife than intensive farming. As Myanmar is undergoing rapid modernization, subsistence farming may shift to intensive agriculture, resulting in increased threats to species of conservation concern such as the green peafowl Pavo muticus. Here we investigate habitat use of the green peafowl in a low intensity agricultural landscape surrounding a small forest fragment in southern Shan State, Myanmar. The forest belongs to Nan Kone Buddha Monastery and the green peafowl is protected from hunting in the area on the basis of religious beliefs. We established three survey transects with a total length of 3,414 m. During February 2016-January 2017 we conducted surveys twice daily for 4 consecutive days every month, walking all transects in both directions in the mornings and afternoons and recording visual and auditory peafowl encounters. We estimated peafowl density to be 2.63 animals $/ \mathrm{km}^{2}$ in the less disturbed western part of the study area and 1.13 animals $/ \mathrm{km}^{2}$ in the eastern part, which had higher levels of human disturbance. The peafowl's habitat use was significantly non-random, with forest patches being the most utilized habitat, followed by croplands. Within a $300 \mathrm{~m}$ buffer zone around the forest patch, the order of habitat preference was crop $>$ scrub $>$ fallow, with crop significantly preferred over the other two habitats. We conclude that preserved isolated forest blocks adjacent to community-managed agricultural areas are important for green peafowl conservation, and discuss the implications for long-term conservation management of the species.
\end{abstract}

Keywords Agriculture, Buddhist monastery, compositional analysis, green peafowl, fragmented forest, Myanmar, Pavo muticus, Shan plateau

NAy Mro ShwE ${ }^{*}$ (Corresponding author), Niti SukUmaL and Tommaso SAVIN Conservation Ecology Program, King Mongkut's University of Technology Thonburi, Bangkok, Thailand. E-mail naymyo.shwe@fauna-flora.org

Khin Maung Oo Pwe Hla Environmental Conservation and Development, Pwe Hla, Myanmar

Simon Dowell Chester Zoo, Upton-by-Chester, Chester, UK

Stephen Browne Fauna \& Flora International, Cambridge, UK

${ }^{*}$ Also at: Fauna \& Flora International, Cambridge, UK

Received 22 January 2019. Revision requested 12 February 2019.

Accepted 26 February 2019. First published online 19 February 2020.

\section{Introduction}

ne of the principal causes of global biodiversity declines is habitat loss as a result of land conversion (Gibson et al., 2011; Joppa et al., 2016; Gosper et al., 2019), mainly for agriculture (Benton et al., 2002; Koh et al., 2008; Clay, 2013). Intensive farming systems affect the dynamics of bird assemblages by causing the extinction of habitat specialists (Bretagnolle et al., 2019). Farmland birds and Galliformes in particular are declining across Europe because of agricultural intensification (Stoate et al., 2001; Wretenberg et al., 2006; Báldi \& Batáry, 2011).

By contrast, low intensity and subsistence agriculture have fewer negative effects on biodiversity, because of traditional, low impact farming practices and the preservation of more heterogeneous landscapes (Fox, 2004; Laiolo et al., 2004; Verhulst et al., 2004; Giupponi et al., 2006; Assandri et al., 2018). Furthermore, forest edges resulting from habitat fragmentation following agricultural conversion can provide vital habitats for some forest birds (Imbeau et al., 2003).

In Myanmar agriculture is still largely low intensity, with low inputs and minimal use of machinery, providing local subsistence crops in most parts of the country (FAO/WFP, 2016). With political change and accelerating human development, however, agricultural practice will probably have an increased impact on biodiversity in the near future. This is particularly important as c. $70 \%$ of the country's key biodiversity areas are outside legally protected areas (Tordoff et al., 2005). Traditional forest management by local communities is more effective than exclusive management by government (Nelson \& Chomitz, 2009; Li et al., 2014), helping communities integrate cultural values with benefits for both biodiversity and human well-being (Delisle et al., 2018; Infield et al., 2018; Schneider, 2018).

The green peafowl Pavo muticus is categorized as Endangered because of hunting and habitat loss resulting from large-scale agricultural conversion (BirdLife International, 2014). Formerly ranging across much of South-east Asia, from north-east India to Java, Indonesia (Delacour, 1977; McGowan et al., 1998), its range and abundance have decreased dramatically and it now only survives in small isolated populations (Sukumal et al., 2020). In Myanmar the green peafowl mostly occurs outside protected areas and there is little information on its status since 1945 (BirdLife International, 2001). A viable population was recently found 


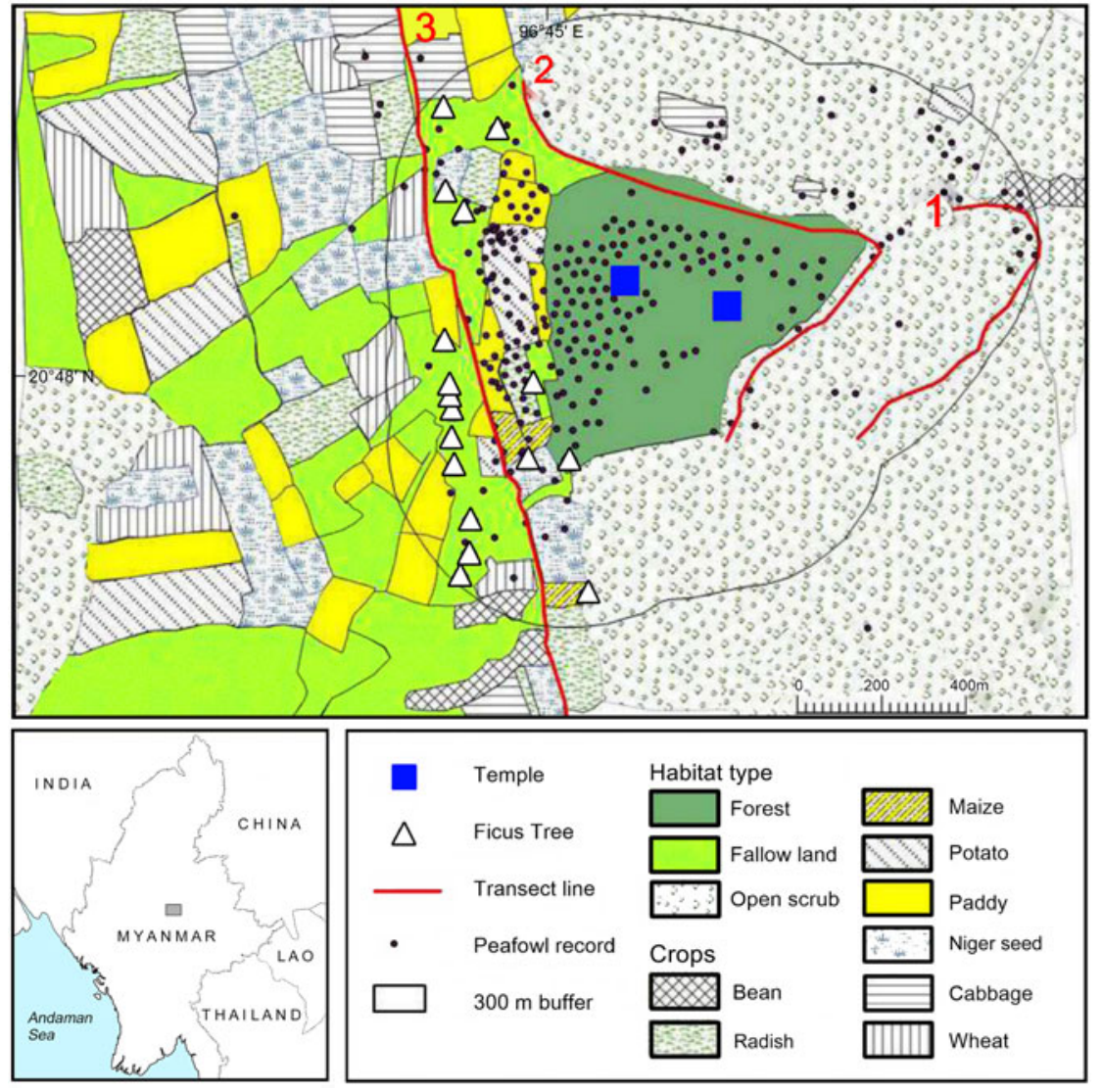

FIG. 1 The study area at Nan Kone Monastery, near Nan Kone village, Pindaya township, southern Shan State, Myanmar, with habitat types and records of the green peafowl Pavo muticus. The $300 \mathrm{~m}$ buffer around the forest was used in the compositional analysis. inhabiting a subsistence agriculture landscape surrounding an isolated forest patch occupied by a Theravada Buddhist monastery in Pwe Hla village, southern Shan State, Myanmar. In this area the species is not hunted by the local community in accordance with Buddhist precept. However, it is unclear how the population could be affected by possible future changes in agricultural practices.

Using the green peafowl as a model for species occurring in forest-agriculture edge habitats, we investigated how the animals respond to different crop patterns in an agricultural landscape surrounding a forest fragment managed by Buddhist monks. The objectives of this study were to (1) determine the density and abundance of the green peafowl in an agricultural area, (2) investigate the use of cropland by green peafowl living in forest fragments in an agricultural landscape and (3) present recommendations for sustainable management for this species in this area.

\section{Study area}

The study was conducted at Nan Kone Monastery, southern Shan State, Myanmar (Fig. 1). The area is at altitudes of 1,300-1,500 $\mathrm{m}$, with a mean maximum monthly temperature of $33{ }^{\circ} \mathrm{C}$ in April and a mean monthly minimum of $15^{\circ} \mathrm{C}$ in December, and annual rainfall of $1,921 \mathrm{~mm}(1-$ $255 \mathrm{~mm}$ per month). The area has a cold dry season (December-February), a hot dry season (March-April) and a wet season (May-November; Htwe et al., 2015). There are scattered native Ficus sp. trees that were planted over 100 years ago along the roads, and large water bodies are absent in the study area.

There are two distinct sections in the $2.872 \mathrm{~km}^{2}$ study area. In the eastern part, the remaining forest is little disturbed, big trees are absent, less land is cultivated and the landscape is dominated by open scrub. The western part is mostly used for growing crops, interspersed with large Ficus trees, and human disturbance (by farmers and villagers) is higher in this area (Fig. 1).

\section{Methods}

\section{Habitat utilization and density estimation}

We established three line transects with a total length of $3,414 \mathrm{~m}$ (transect $1=722 \mathrm{~m}$, transect $2=1,176 \mathrm{~m}$, transect $3=1,516 \mathrm{~m}$ ): two (transects 1 and 2 ) in the eastern part of the forest patch and one (transect 3) in the western part (Fig. 1). We walked transects in both directions twice daily (07.0009.00 and 16.00-18.00), on 4 consecutive days every month, for 12 months (February 2016-January 2017), at a speed of $1 \mathrm{~km} / \mathrm{h}$. Observers rotated between transects to avoid bias.

When a green peafowl was seen or heard, we recorded the number of individuals, whether they were adults or chicks, sex, the habitat being used and behaviour (feeding, 
TABLE 1 Habitat type, area cover and crop season in the Han Kone Monastery area, Pwe Hla, Pindaya township, Shan State, Myanmar (Fig. 1).

\begin{tabular}{|c|c|c|c|c|c|}
\hline Habitat \& crop types & Area $\left(\mathrm{km}^{2}\right)$ & Area $(\%)$ & Growing season & Harvest season & Chemical usage \\
\hline Forest & 0.23253 & 8.10 & & & no \\
\hline Scrub & 1.23655 & 43.05 & & & no \\
\hline Fallow land & 0.52734 & 18.36 & & & no \\
\hline $\begin{array}{l}\text { Pulses (black gram Phaseolus mungo, } \\
\text { chickpeas Cicer arietinum) }\end{array}$ & 0.05572 & 1.94 & Nov. & Mar./Apr. & yes \\
\hline Cabbage Brassica oleracea var & 0.07728 & 2.69 & May/June & July/Aug. & yes \\
\hline Radish Raphanus raphanistrum $\times$ sativus & 0.10906 & 3.80 & Sep./Oct. & Mar. & yes \\
\hline Maize Zea mays & 0.01083 & 0.38 & May & Sep. & no \\
\hline Potato Solanum tuberosum & 0.13556 & 4.72 & Apr. & July & yes \\
\hline Paddy Oryza sativa & 0.18995 & 6.61 & June & Nov. & no \\
\hline Niger seed Guizotia abyssinica & 0.20660 & 7.19 & Sep. & Feb. & no \\
\hline Wheat Triticum sp. & 0.09101 & 3.17 & Sep. & Mar. & no \\
\hline Total & 2.87243 & 100.00 & & & \\
\hline
\end{tabular}

displaying, roosting). We recorded the birds' geographical location on paper maps and later entered the data into a GIS. We also recorded the presence of any natural predators and threats to the peafowl, and pesticide and herbicide use when we observed farmers spraying their fields.

We defined 11 micro-habitats (Table 1 ) in four main habitat categories: (1) forest, mainly in the area of the monastery, dominated by large pine and evergreen trees with an understory of thick, thorny scrub, (2) scrub, mainly in the eastern part of the study area, with rocky ground, sparse agave plants and thick thorny scrub, (3) cropland, consisting of rice paddy, radish, cabbage, potato, maize, bean, wheat and niger seed fields (Table 1), and (4) fallow, uncultivated fields with no crops grown during the study period and including marginal areas between croplands, ditches, bullock cart tracks and roads.

We digitized habitat boundaries from Google Earth (Google, Mountain View, USA) and conducted monthly checks by walking the transects before the surveys to confirm crop types and note any seasonal crop pattern changes (some crops such as potato and niger seed were alternated in the same patches during the study period). We calculated the coverage of each micro-habitat using ArcGIS 10.3 (Esri, Redlands, USA). Additionally, we asked farmers informal questions concerning their use of pesticides in the management of different crop types.

\section{Data analysis}

We estimated green peafowl density separately for the eastern and western parts of the study area, using a Hazard/ Cosine model in DISTANCE 6.2 (Buckland et al., 2001). We analysed macro-habitat use by the green peafowl using compositional analysis, via Smith Ecology Compos Analysis 6.3a (Smith Ecology Ltd, Abergavenny, UK), which indicates any statistically significant preference or avoidance of habitat types compared to their availability, and ranks habitats in order of preference (Aebischer et al., 1993; Bo et al., 2009). We substituted all proportional values (habitat use divided by habitat availability) of zero with 0.01 (Smith et al., 2015).

To assess the relative importance of different habitats at the forest edge for peafowl, we created a $300 \mathrm{~m}$ wide buffer from the forest edge (this included $86 \%$ of all peafowl detections), combined all crop types in a single category and compared this against forest, scrub and fallow. We used a minimum of 1,000 iterations in all tests (Smith et al., 2015).

\section{Results}

We detected the green peafowl a total of 359 times during the 12 months of the survey. Over this period, a total of five individual males were recorded in the area. Courtship displays were recorded during January-March. A nest with three eggs was found in May. We recorded chicks with females (five detections) during May-August. Dividing the study duration into periods of 4 months, the highest proportion of detections (calls and direct sightings) was during January-April (194; 54\%), coinciding with the main display and mating period, and the lowest during the nesting period, May-August (37;10\%), when females were predominantly incubating eggs and males were not displaying. The remaining detections were in the non-breeding period, SeptemberDecember $(125 ; 36 \%)$.

Green peafowl density was 2.63 animals $/ \mathrm{km}^{2}$ in the western and 1.13 animals $/ \mathrm{km}^{2}$ in the eastern part (Table 2). The total population was estimated to be 22 individuals across the entire study area, with six individuals in the eastern and 16 in the western part (Table 2), although it is possible that individuals moved between the two parts of the study area.

Habitat selection in relation to availability was significantly non-random (Wilk's $\lambda=0.0115, \chi^{2}=53.57, \mathrm{df}=10$, 
TABLE 2 Estimate of density and abundance of the green peafowl Pavo muticus in the eastern and western parts of the study area (Fig. 1), using distance sampling. The Table also shows the $95 \%$ confidence intervals of the estimates (CI) and the coefficient of variation of the abundance estimates $(\% \mathrm{CV})$.

\begin{tabular}{|c|c|c|c|}
\hline & Estimate & $95 \% \mathrm{CI}$ & $\% \mathrm{CV}$ \\
\hline \multicolumn{4}{|c|}{ Eastern part (total transect length $1,898 \mathrm{~m}$ ) } \\
\hline Density (animals $/ \mathrm{km}^{2}$ ) & 1.13 & $0.3295-3.8651$ & \\
\hline Abundance & 6 & $2-19$ & 69.55 \\
\hline \multicolumn{4}{|c|}{ Western part (total transect length $1,516 \mathrm{~m}$ ) } \\
\hline Density (animals $/ \mathrm{km}^{2}$ ) & 2.63 & $2.2839-3.0236$ & \\
\hline Abundance & 16 & $14-18$ & 7.17 \\
\hline
\end{tabular}

$\mathrm{P}<0.0001$ ). A simplified ranking matrix (Table 3 ) indicates that forest was the most utilized habitat $(\mathrm{P}<0.0001)$ and was significantly preferred over all crop types, except rice paddy. The second most utilized habitat was rice paddy and this was significantly preferred in relation to its availability compared to cabbage, radish, niger seed and wheat (Table 3).

Of the 359 detections, 190 (53\%) were in forest, and in all crop types combined there were only 36 detections (c. 10\%). A simplified matrix presenting further details on habitat use, with all crop types combined into a single cropland category and compared against forest, scrub and fallow, is shown in Table 4. Habitats in order of preference were forest $>$ cropland $>$ scrub $>$ fallow, but only forest was significantly preferred in relation to its availability. Habitat utilization was not significantly different between cropland, scrub and fallow.

The forest patch formed the centre of the distribution of bird detections (Fig. 1) and the number of detections decreased with increasing distance from the forest (Fig. 2). To further examine the use of croplands at the forest edge, we defined a buffer zone around the forest. The majority (86.3\%) of peafowl detections outside the forest were within $300 \mathrm{~m}$ of the forest edge (Fig. 1).

A comparison of habitat use and availability within the $300 \mathrm{~m}$ buffer showed that habitat selection was significantly non-random (Wilk's $\lambda=0.1369, \chi^{2}=23.86, \mathrm{df}=2$, $\mathrm{P}<0.0001$ ). A simplified ranking matrix (Table 4 ) indicates that the order of habitat preference was cropland $>$ scrub $>$ fallow $(\mathrm{P}<0.0001)$, with cropland significantly preferred over the other two habitats. There was no significant difference between the utilization of scrub and fallow.

\section{Discussion}

Our density estimates from an agricultural landscape in Myanmar (2.63 and 1.13 birds $/ \mathrm{km}^{2}$ ) are within the range of densities estimated in protected areas in other parts of the green peafowl's range: Yok Don National Park ( 0.25 calling birds $/ \mathrm{km}^{2}$ ) and Cat Tien National Park (3.03 calling birds $/ \mathrm{km}^{2}$ ) in Viet Nam (Sukumal et al., 2015); Siem Pang Wildlife Sanctuary (1.70 calling birds $/ \mathrm{km}^{2}$; Loveridge et al., 2017), and Seima Protection Forest (o.30 calling birds $/ \mathrm{km}^{2}$; Nuttall et al., 2017) in Cambodia; and Huai Kha Khaeng Wildlife Sanctuary (1.13-11.34 calling birds $/ \mathrm{km}^{2}$ ) in Thailand (Sukumal et al., 2017). However, our survey included sightings (of males and females) as well as auditory detection of calling birds, thus comparison with density estimates based on calling birds alone (which are primarily males) should be treated with caution.

Forest appears to be a key habitat for the green peafowl in our study area, although elsewhere the species is mostly found in open habitat with sparse ground vegetation cover, such as certain types of crops, shrub and fallow land. Studies in natural forest have shown the birds to occupy open areas within forest, such as alongside river beds, at certain times of the year (Sukumal et al., 2017). The main threat to the species in our study area is predation by feral dogs; we observed three breeding males being killed by dogs during February-March 2018. We also saw birds flying up into the branches of mature trees when attacked by dogs, suggesting forest provides some protection from predators. This could explain why peafowl primarily utilize areas within $300 \mathrm{~m}$ of the forest edge, as remaining close to trees could allow them to escape and reduce the risk of predation (Lawson \& Johnson, 1982).

Our findings also suggest that peafowl moving out of the forest prefer cropland over scrub and fallow land. Our data are based on both observations and call records from the different habitats. Detectability within cropland and fallow areas was similar and the scrub consisted of small patches of scattered bushes, where peafowl were highly visible. Croplands are potential feeding grounds for adult birds and can provide the invertebrates that are the main component of the diet of Galliformes chicks in the first 6-8 weeks (Potts, 1986; Rands, 1988). The scrub habitat type in the study area could provide fewer feeding opportunities (Sukumal et al., 2015). Fallow land potentially harbours insect food, but the vegetation may be too dense for young chicks, which are vulnerable to chilling when brushing against wet vegetation (Reynolds et al., 1988). The dense structure of this habitat may also compromise the birds' ability to detect approaching predators (Reynolds et al., 1988).

Given the apparent importance of cropland for feeding, the use of pesticides probably presents a threat to the species, through direct toxicity or via their effect on the supply of invertebrate food, thus potentially affecting chick survival rate (Stanton et al., 2018). In Galliformes such effects have been reported for the grey partridge Perdix perdix (Potts, 1986; Warren et al., 2017), red-legged partridge Alectoris rufa and pheasant Phasianus colchicus (Rands, 1986). The use of pesticides also directly affected adult mortality in the blue peafowl Pavo cristatus (Panigrahy et al., 1979) and northern bobwhite Colinus virginianus (Ertl et al., 2018). In 
TABLE 3 Simplified ranking matrix from compositional analysis for all available habitat types across the entire study area, showing whether the habitat type in the row is selected $(+)$, significantly selected $(+++)$, avoided $(-)$ or significantly avoided (---) relative to the habitat type in the column $(t$ test $\mathrm{P}<0.0001)$.

\begin{tabular}{|c|c|c|c|c|c|c|c|c|c|c|c|c|}
\hline & Bean & Cabbage & Scrub & Fallow & Forest & Radish & Maize & Potato & Paddy & Niger seed & Wheat & Rank \\
\hline Forest & +++ & +++ & +++ & +++ & & +++ & +++ & +++ & + & +++ & +++ & 10 \\
\hline Paddy & + & +++ & + & + & - & +++ & + & + & & +++ & +++ & 9 \\
\hline Open scrub & + & + & & + & --- & + & + & + & - & +++ & + & 8 \\
\hline Fallow & + & + & - & & --- & + & + & + & - & + & + & 7 \\
\hline Maize & + & + & - & - & --- & + & & + & - & + & + & 6 \\
\hline Potato & + & + & - & - & --- & + & - & & - & + & + & 5 \\
\hline Cabbage & + & & - & - & --- & + & - & - & --- & + & + & 4 \\
\hline Bean & & - & - & - & --- & + & - & - & - & + & + & 3 \\
\hline Radish & - & - & - & - & --- & & - & - & --- & + & + & 2 \\
\hline Wheat & - & - & - & - & --- & - & - & - & --- & + & & 1 \\
\hline Niger seed & - & - & --- & - & --- & - & - & - & --- & & - & 0 \\
\hline
\end{tabular}

TABLE 4 Simplified ranking matrix for detections in all habitat types (including forest) and within the $300 \mathrm{~m}$ buffer zone from the forest edge (excluding forest), showing whether the habitat type in the row is selected $(+)$, significantly selected $(+++)$, avoided $(-)$ or significantly avoided (---) relative to the habitat type in the column.

\begin{tabular}{|c|c|c|c|c|c|}
\hline & Forest & Scrub & Fallow & Cropland & Rank \\
\hline \multicolumn{6}{|c|}{ All habitat types $(t$ test $\mathrm{P}<0.1)$} \\
\hline Forest & & +++ & +++ & + & 3 \\
\hline Cropland & - & + & + & & 2 \\
\hline Scrub & --- & & + & - & 1 \\
\hline Fallow & --- & - & & - & 0 \\
\hline \multicolumn{6}{|c|}{$300 \mathrm{~m}$ buffer from forest edge ( $t$ test $\mathrm{P}<0.0001$ ) } \\
\hline Cropland & & +++ & +++ & & 2 \\
\hline Scrub & & & + & --- & 1 \\
\hline Fallow & & - & & --- & 0 \\
\hline
\end{tabular}

addition, agricultural intensification affects other grounddwelling birds such as the South American Tinamiformes (Thompson, 2004). According to information obtained from the local farming community, pesticides (both herbicides and insecticides) are used on cabbage, beans, radish and potato crops in the area, but not on rice paddy, wheat, niger seed and maize (Table 1). Our findings suggest the birds show a preference for rice paddy, one of the crops that is not currently treated with pesticides, over other crop types (Table 3).

Agricultural landscapes are often considered to be of little conservation value (Sreekar et al., 2015), but our study highlights the importance of small patches of forest outside protected areas for the survival of threatened species. In addition to the green peafowl we recorded mammals such as the barking deer Muntiacus muntjak and yellow throated martin Martes flavigula in the small forest patch, and 81 bird species. Habitat fragments outside legally protected areas are becoming increasingly important for biodiversity conservation in regions of rapid human population growth such as South-east Asia (Sodhi et al., 2010). The conservation value of our study site may be typical for the wider Shan

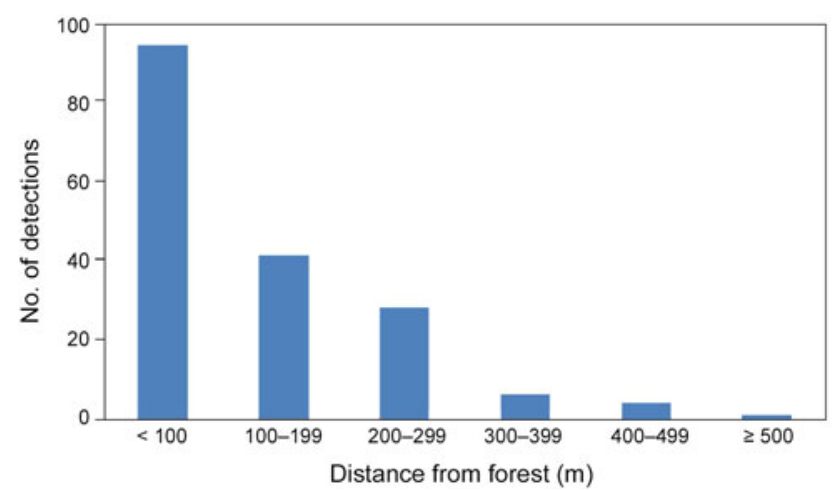

FIG. 2 Distance from forest and number of green peafowl detections in cropland.

State landscape, where there are several remnant isolated forest patches surrounded by traditional agricultural areas. However, Myanmar's rapid economic development could change this matrix in the near future if traditional smallscale agriculture is converted to industrialized monocultures, as observed in neighbouring countries.

An important factor supporting the conservation of the green peafowl at the Pwe Hla study site is the strong influence of the resident Theravada Buddhist clergy on the local community (Gogoi, 2018; Schneider, 2018). Abstinence from hunting the green peafowl can be attributed directly to the belief that the species represents one of the 108 distinguishing marks on the soles of the Buddha's feet. The protection provided by religious beliefs needs to be considered when planning future conservation efforts for this species.

The subpopulation of green peafowl at Pwe Hla is a small but significant one for this Endangered species, and is potentially part of a larger population occurring outside protected areas in the agricultural landscape of Shan State and beyond. To ensure the sustainable management of this population we recommend restricted use of agricultural pesticides, particularly around patches of remnant forests which provide roosting and nesting sites for the species. 
We also recommend control of feral dogs and continued support for the Buddhist traditions that provide protection for the birds from hunting and trapping.

Acknowledgments We thank Pwe Hla Environmental Conservation and Development and Friends of Wildlife for their support, the honourable monks at Nan Kone Monasteries for granting permission to use the surrounding area for the survey and for their support, Scott Wilson for his support in GIS work, and Matthew Grainger for valuable comments and suggestions. NMS was sponsored by a Rufford Small Grant (19271-1), and the Conservation Ecology Program, King Mongkut's University of Technology Thonburi, Thailand, that provided $\mathrm{PhD}$ scholarship for NMS (18/2558). NS was supported by the Royal Golden Jubilee PhD Program, Thailand (PHD/0105/2553). We thank Fauna \& Flora International for permission to NMS to conduct this research.

Author contributions Study design: NMS, NS, TS; data collection: NMS, KMO; data analysis and writing: NMS, NS, SD, SB, TS.

\section{Conflicts of interest None.}

Ethical standards This research abided by the Oryx guidelines on ethical standards. It was observational and designed to ensure wildlife, study area and local communities were not harmed or disturbed.

\section{References}

Aebischer, N.J., Robertson, P.A. \& Kenward, R.E. (1993) Compositional analysis of habitat use from animal radio-tracking data. Ecology, 74, 1313-1325.

Assandri, G., Bogliani, G., Pedrini, P. \& Brambilla, M. (2018) Beautiful agricultural landscapes promote cultural ecosystem services and biodiversity conservation. Agriculture, Ecosystems \& Environment, 256, 200-210.

BÁLDI, A. \& BATÁRY, P. (2011) The past and future of farmland birds in Hungary. Bird Study, 58, 365-377.

Benton, T.G., Bryant, D.M., Cole, L. \& Crick, H.Q. (2002) Linking agricultural practice to insect and bird populations: a historical study over three decades. Journal of Applied Ecology, 39, 673-687.

Birdife International (2001) Threatened Birds of Asia: The BirdLife International Red Data Book. BirdLife International, Cambridge, UK.

Birdife International (2014) Species factsheet: Pavo muticus. BirdLife International, Cambridge, UK.

Bo, D., Dowell, S.D., Garson, P.J. \& Fen-Qi, H. (2009) Habitat utilisation by the threatened Sichuan Partridge Arborophila rufipectus: consequences for managing newly protected areas in southern China. Bird Conservation International, 19, 187-198.

Bretagnolle, V., Siriwardena, G., Miguet, P., Henckel, L. \& KLEIJN, D. (2019) Local and landscape scale effects of heterogeneity in shaping bird communities and population dynamics: crop-grassland interactions. In Agroecosystem Diversity (eds G. Lemaire, P. Carvalho, S. Kronberg \& S. Recous), pp. 231-243. Academic Press, Cambridge, USA.

Buckland, S.T., Anderson, D.R., Burnham, K.P., Laake, J.I., Borchers, D.L. \& Thomas, L. (2001) Introduction to Distance Sampling: Estimating Abundance of Biological Population. Oxford University Press, New York, USA.

CLAY, J. (2013) World Agriculture and the Environment: A Commodityby-Commodity Guide to Impacts and Practices. Island Press, Washington, DC, USA.
Delacour, J. (1977) The Pheasants of the World. 2nd edition. Spur Publications, Hindhead, UK.

Delisle, A., Kim, M.K., Stoeckl, N., Lui, F.W. \& Marsh, H. (2018) The socio-cultural benefits and costs of the traditional hunting of dugongs Dugong dugon and green turtles Chelonia mydas in Torres Strait, Australia. Oryx, 52, 250-261.

Ertl, H.M., Mora, M.A., Brightsmith, D.J. \& Navarro-Alberto, J.A. (2018) Potential impact of neonicotinoid use on Northern bobwhite (Colinus virginianus) in Texas: a historical analysis. PLOS ONE, 13, eo19110o.

FAO/WFP (2016) Crop and Food Security Assessment Mission to Myanmar: Special Report. Food and Agriculture Organization of the United Nations World Food Programme, Rome, Italy.

Fox, A.D. (2004) Has Danish agriculture maintained farmland bird populations? Journal of Applied Ecology, 41, 427-439.

Gibson, L., Lee, T.M., Koh, L.P., Brook, B.W., Gardner, T.A., BARLOW, J. et al. (2011) Primary forests are irreplaceable for sustaining tropical biodiversity. Nature, 478, 378-381.

Giupponi, C., Ramanzin, M., Sturaro, E. \& Fuser, S. (2006) Climate and land use changes, biodiversity and agri-environmental measures in the Belluno province, Italy. Environmental Science \& Policy, 9, 163-173.

GogoI, M. (2018) Emotional coping among communities affected by wildlife-caused damage in north-east India: opportunities for building tolerance and improving conservation outcomes. Oryx, 52, 214-219.

Gosper, C.R., Fox, E., Burbidge, A.H., Craig, M.D., Douglas, T.K., Fitzsimons, J.A. et al. (2019) Multi-century periods since fire in an intact woodland landscape favour bird species declining in an adjacent agricultural region. Biological Conservation, 230, 82-90.

Htwe, T. N., Brinkmann, K. \& Buerkert, A. (2015) Spatio-temporal assessment of soil erosion risk in different agricultural zones of the Inle Lake region, southern Shan State, Myanmar. Environmental Monitoring and Assessment, 187, 617.

Imbeau, L., Drapeau, P. \& Mönkkönen, M. (2003) Are forest birds categorised as 'edge species' strictly associated with edges? Ecography, 26, 514-520.

Infield, M., Entwistle, A., Anthem, H., Mugisha, A. \& Phillips, K. (2018) Reflections on cultural values approaches to conservation: lessons from 20 years of implementation. Oryx, 52, 220-230.

Joppa, L.N., O’Connor, B., Visconti, P., Smith, C., Geldmann, J., Hoffmann, M. et al. (2016) Filling in biodiversity threat gaps. Science, 352, 416-418.

$\mathrm{KoH}$, L.P. \& Wilcove, D.S. (2008) Is oil palm agriculture really destroying tropical biodiversity? Conservation Letters, 1, 60-64.

Laiolo, P., Dondero, F., Ciliento, E. \& Rolando, A. (2004) Consequences of pastoral abandonment for the structure and diversity of the alpine avifauna. Journal of Applied Ecology, 41, 294-304.

Lawson, B. \& Johnson, R. (1982) Mountain sheep. In Wild Mammals of North America (eds J.A. Chapman \& G.A. Feldhamer), pp. 10361055. Johns Hopkins University Press, Baltimore, USA.

Li, J., WANG, D., Yin, H., ZhaXi, D., Jiagong, Z., Schaller, G.B. \& XIAO, L. (2014) Role of Tibetan Buddhist monasteries in snow leopard conservation. Conservation Biology, 28, 87-94.

Loveridge, R., Kidney, D., Ty, S., Eang, S., Eames, C. E. \& Borchers, D. (2017) First systematic survey of green peafowl Pavo muticus in northeastern Cambodia reveals a population stronghold and preference for disappearing riverine habitat. Cambodian Journal of Natural History, 2017, 157-167.

McGowan, P.J.K., Duckworth, J.W., Xianji, W., van Balen, B., XiaOjun, Y., Khan, K.M. \& KaUL, R. (1998) A review of the status of the green peafowl Pavo muticus and recommendations for future action. Bird Conservation International, 8, 331-348.

Nelson, A. \& Chomitz, K.M. (2009) Protected Area Effectiveness in Reducing Tropical Deforestation. A Global Analysis of the Impact of 
Protection Status (English). IEG Evaluation Brief No. 7. World Bank, Washington, DC, USA.

Nuttall, M., Nut, M., UnG, V. \& O’Kelly, H.A. (2017) Abundance estimates for the Endangered green peafowl Pavo muticus in Cambodia: identification of a globally important site for conservation. Bird Conservation International, 27, 127-39.

Panigrahy, B., Grumbles, L.C. \& Hall, C.F. (1979) Insecticide poisoning in peafowls and lead poisoning in a cockatoo. Avian Diseases, 23, 760-762.

Potтs, G. (1986) The Partridge: Pesticides, Predation and Conservation. Harper Collins, New York, USA.

RANDs, M.R.W. (1986) The survival of gamebird (Galliformes) chicks in relation to pesticide use on cereals. Ibis, 128, 57-64.

RANDS, M.R.W. (1988) Habitat quality and gamebird ecology. In Ecology and Management of Gamebirds (eds P.J. Hudson \& M.R.W. Rands), Chapter 6, pp. 49-54. BSP Professional Books, Oxford, UK.

Reynolds, J.C., Angelstam, P. \& Redpath, S. (1988) Predators, their ecology and impact on gamebird populations. Chapter 4. In Ecology and Management of Gamebirds (eds P.J. Hudson and M.R.W. Rands), BSP Professional Books, Oxford, UK.

Schneider, H. (2018) What role for culture in conservation? Oryx, 52, 199-200.

Smith, P.G. (2015) Compos Analysis Version 6.3 User's Guide Issue 2. Smith Ecology Ltd., Abergavenny, UK.

Sodhi, N.S., Pin, L., Clements, R., Wanger, T.C., Hill, J.K., Hamer, K.C. \& Ming, T. (2010) Conserving Southeast Asian forest biodiversity in human-modified landscapes. Biological Conservation, 143, 2375-2384.

Sreekar, R., Zhang, K., XU, J., Harrison, R.D. (2015) Yet another empty forest: considering the conservation value of a recently established tropical nature reserve. PLOS ONE, 10, e0117920.

Stanton, R.L., Morrissey, C.A. \& Clark, R.G. (2018) Analysis of trends and agricultural drivers of farmland bird declines in North
America: a review. Agriculture, Ecosystems \& Environment, 254, 244-254.

Stoate, C., Boatman, N.D., Borralho, R.J., Carvalho, C.R., De SNOO, G.R. \& EdEN, P. (2001) Ecological impacts of arable intensification in Europe. Journal of Environmental Management, $63,337-365$.

Sukumal, N., McGowan, P.J. \& SAvini, T. (2015) Change in status of green peafowl Pavo muticus (Family Phasianidae) in Southcentral Vietnam: a comparison over 15 years. Global Ecology and Conservation, 3, 11-19.

Sukumal, N., Dowell, S.D. \& SAvini, T. (2017) Micro-habitat selection and population recovery of the Endangered green peafowl Pavo muticus in western Thailand: implications for conservation guidance. Bird Conservation International, 27, 414-430.

Sukumal, N., Dowell, S.D. \& SAvini, T. (2020) Modelling occurrence probability of the Endangered green peafowl Pavo muticus in mainland South-east Asia: applications for landscape conservation and management. Oryx, 54, 30-39.

Thompson, J.J. (2004) Tinamous and agriculture: lessons learned from the Galliformes. Ornitologia Neotropical, 15, 301-307.

Tordoff, A.W., Eames, J.C., Eberhardt, K., Baltzer, M.C., Davidson, P., Leimgruber, P. et al. (2005). Myanmar: Investment Opportunities in Biodiversity Conservation. BirdLife International, Yangon, Myanmar.

Verhulst, J., BÁldi, A. \& Kleijn, D. (2004) Relationship between land-use intensity and species richness and abundance of birds in Hungary. Agriculture, Ecosystems \& Environment, 104, 465-473.

Warren, P., Hornby, T. \& Baines, D. (2017) Habitat use, nest-sites and chick diet of Grey Partridge Perdix perdix on hill farms in north east England. Bird Study, 64, 138-145.

Wretenberg, J., Lindström, Å., Svensson, S., Thierfelder, T. \& PÄrT, T. (2006) Population trends of farmland birds in Sweden and England: similar trends but different patterns of agricultural intensification. Journal of Applied Ecology, 43, 1110-1120. 